\title{
Effect of nitrogen fertilization and decapitation stress on Triticum aestivum L. (Wheat) productivity
}

Muhammad Islam ${ }^{1 *}$, Shazma Anwar ${ }^{1}$, Anjum ${ }^{1}$, Bilal Khan ${ }^{1}$, Wajid Ali $\mathrm{Shah}^{2}$, Murad Ali ${ }^{3}$, Subhan Uddin ${ }^{4}$, Nadar Khan ${ }^{5}$ and Nisar Ali ${ }^{6}$

1. Department of Agronomy, The University of Agriculture, Peshawar-Pakistan

2. Department of Agronomy, Bacha Khan University, Charsadda-Pakistan

3. Center for Biotechnology \& Microbiology, University of Swat-Pakistan

4. Department of Agricultural Mechanization, The University of Agriculture, Peshawar-Pakistan

5. Department of Animal Nutrition, The University of Agriculture, Peshawar-Pakistan

6. Department of Soil and Environmental Sciences, The University of Agriculture, Peshawar-Pakistan

*Corresponding author's email: islamswati439@yahoo.com

Citation

Muhammad Islam, Shazma Anwar, Anjum, Bilal Khan, Wajid Ali Shah, Murad Ali, Subhan Uddin, Nadar Khan and Nisar Ali. Effect of nitrogen fertilization and decapitation stress on Triticum aestivum L. (Wheat) productivity. Pure and Applied Biology. Vol. 5, Issue 2, 2016, pp317-325. http://dx.doi.org/10.19045/bspab.2016.50041

\begin{tabular}{llll}
\hline Received: 11/11/2015 & Revised: 09/03/2016 & Accepted: 16/03/2016 & Online First: 21/03/2016 \\
\hline
\end{tabular}

\section{Abstract}

The experiment entitled "effect of nitrogen fertilization and decapitation stress on wheat productivity was laid out in a randomized complete block with split plot arrangement having three replications during winter 2011-12. Variety Siran-2010 was sown at the rate of $120 \mathrm{~kg} \mathrm{ha}^{-1}$. Decapitation stress (cutting) was compared with no cutting in main plots while nitrogen levels $\left(0,100,140 \& 180 \mathrm{~kg} \mathrm{ha}^{-1}\right)$ were assigned to the sub plots. Half of the nitrogen was applied at first irrigation, whereas the remaining half was used 70 days after sowing. Decapitation was done by cutting the respective plots with sickle 70 days after sowing. Results of the experiment showed that no cut plots resulted highest number of spikes $\mathrm{m}^{-2}$ (388), grains spike $^{-1}$ (53.2), thousand grains weight (39.43g), biological yield (10856 kg ha-1) and grain yield (3741 kg ha-1). Cut plots gave additional forage yield of $3243 \mathrm{~kg} \mathrm{ha}^{-1}$ and therefore gave additional income of Rs. $4067 \mathrm{ha}^{-1}$ over control respectively. Maximum spikes $\mathrm{m}^{-2}$ (389), grains $\operatorname{spike}^{-1}$ (56.0) and thousand grains weight $(40.22 \mathrm{~g})$ was produced by nitrogen applied at the rate of $140 \mathrm{~kg} \mathrm{ha}^{-1}$. Whereas maximum biological yield (11435 kg ha-1), grain yield (4246 kg ha-1), moisture content $(12.814 \%)$ and crude protein content $(12.455 \%)$ was produced by nitrogen at the rate of $180 \mathrm{~kg}$ $\mathrm{ha}^{-1}$. It is concluded that supplied nitrogen @ $140 \mathrm{~kg} \mathrm{ha}^{-1}$ with no decapitation stress seems to be the best choice for wheat producer in the agro-climatic condition of Peshawar valley.

Key Words: Triticum aestivum L. (Wheat); Decapitation; Nitrogen; Yield; Yield components; Economic analysis

\section{Introduction}

Triticum aestivum L. (Wheat) is the first grain crop around the world. Its production is generally for grain purpose, while in countries such as Argentina, Australia, Morocco, Syria and Uruguay, wheat crop is cultivated for grain as well as for fodder purpose. Wheat is the major crop in term of 
area and production [1]. The pasture of wheat is of great value because of its quality and quantity compared to other crops in late fall, winter or early spring season [2]. There is a unique ability in wheat that if its fodder is harvested in the early stage of growth, dual benefits may be obtained as green forage and grain at maturity [3]. In this way the basic demands of food and feed of the over increasing human and livestock population can be overcome from the same field providing perfect management practices[4]. So in order to minimize competition among green forage and grain yield dual purpose wheat cropping is a unique system to maintain quality forage and grain yield from the same piece of land [5]. To get plenty green forage for livestock, dual purpose wheat is applied with additional nourishment to account for nitrogen deletion in form of green forage [6, 7]. In crop productivity nitrogen application is frequently the most limiting variable because it is one of the most important nutrients required by the plant in large quantities. Its application results in vigorous vegetative growth and also enhances yield and milling qualities of the grain [8]. Hence nitrogen application and cutting are important management inputs, which influence forage and grain production of wheat [9]. Keeping in view the increasing demands of grain and green forage, the current study was conducted to determine the optimum nitrogen level suitable for dual purpose wheat.

\section{Materials and methods}

An experiment on the effect of nitrogen fertilization and decapitation stress on Triticum aestivum L. (wheat) productivity was carried out at New Developmental Farm, The University of Agriculture, Peshawar, Pakistan during winter season 2011-12. The site is located at $\left(34^{\circ} 00^{\prime} \mathrm{N}\right.$, $71^{\circ} 30^{\prime}$ E, 510 MASL). The soil of experimental site has Porosity $45.95 \%$,
Texture class; silty clay loam, Clay $40.2 \%$, Silt $51.1 \%$, Sand $8.7 \%$, organic mater $1.50 \mathrm{~g}$ $\mathrm{kg}^{-1}, \mathrm{pH}$ of 8.2 , lime $19 \%$, Total nitrogen $4.25 \mathrm{~g} \mathrm{~kg}^{-1}$, EC $0.7 \mathrm{ds} \mathrm{cm}^{-1},(\%)$ and Bulk Density $1.43 \mathrm{Mg} \mathrm{m}^{-3}$. The EC in water or saturation extract or leachate solution was determined by using EC meter (WTW, Germany). Before analyzing samples, the EC meter was calibrated against $0.1 \mathrm{~N}$ and $0.01 \mathrm{~N} \mathrm{KCl}$ solutions. Soil $\mathrm{pH}$ was determined by taking $10 \mathrm{~g}$ of soil sample in a conical flask and added with $50 \mathrm{~mL}$ of distilled water to make 1:5 soil-water suspensions. The suspension was shaken through a mechanical shaker for 30min and then filtered through Whatmann no. 42. The $\mathrm{pH}$ readings of the samples was noted after calibrating the $\mathrm{pH}$ meter against two buffers with $\mathrm{pH}$ values of 7.01 and 10.1 Organic matter in soil samples was determined by the following formula:

SOM (\%) $=\left[\left(\mathrm{mL}\right.\right.$ of $\left.\mathrm{K}_{2} \mathrm{Cr}_{2} \mathrm{O}_{7} \times \mathrm{N}\right)-\left(\mathrm{mL}\right.$ of $\left.\left.\mathrm{FeSO}_{4} .7 \mathrm{H} 2 \mathrm{O} \times \mathrm{N}\right)\right] \times 0.69$ Weight of soil (g)

The total soil nitrogen was determined following the Kjeldahl method.

Total $\mathrm{N}(\%)=\frac{(\mathrm{S}-\mathrm{B}) \times 0.014 \times 0.005 \times \text { Volume made }}{} \times 100$ Wt. of sample $x \mathrm{ml}$ of extract

Hydrometer method was used for soil texture determination. A $50 \mathrm{~g}$ air-dry soil sample was placed in dispersion cup and sufficient water was added. Then $10 \mathrm{~mL}$ of $1 \mathrm{~N} \mathrm{Na}_{2} \mathrm{Co}_{3}$ was added and the volume of dispersion cup was made to the mark and blend for 10-15 minutes. Then the solution was transferred to a $1000 \mathrm{~mL}$ cylinder. Then the hydrometer was placed into the suspension and the $40 \mathrm{sec}$ reading was recorded. After 2 hours, second reading was recorded. Temperature was noted for both the readings. Calculations were carried out for percent sand, silt and clay, using USDA textural triangle, texture of the soil was determined. The experiment was designed in a randomized complete block design with 
split plot arrangement having three replications. Decapitation stress (cut and no cut) was assigned to main plots, whereas nitrogen levels i.e. rates of nitrogen $\left(0,100,140\right.$ and $\left.180 \mathrm{~kg} \mathrm{ha}^{-1}\right)$ to the sub plots. Urea was applied as a source of nitrogen. Size of the sub plot was $3 \times 4 \mathrm{~m}^{2}$. Row to row space of $30 \mathrm{~cm}$ was maintained. The crop was sown with the help of single row hand drill on a well prepared seed bed. Seeds were planted at the rate of $120 \mathrm{~kg} \mathrm{ha}^{-1}$. Phosphorus at the rate of $60 \mathrm{~kg} \mathrm{ha}^{-1}$ was applied at sowing from DAP. Nitrogen was applied in split doses. First dose was applied at first irrigation about 30 days after sowing, whereas the remaining half dose was applied 70 days after sowing. Decapitation was done by cutting the respective plots with sickle after 70 days of sowing. All other agronomic practices were applied equally. The parameters recorded were fresh forage yield, spikes $\mathrm{m}^{-2}$, grains spike $^{-1}$, thousand grains weight, biological yield, grain yield, moisture content, crude protein content, crude fiber content and net profit. Data regarding fresh forage yield was recorded by cutting the respective plots (70 DAS). Spikes (productive tillers) were counted in four central rows of each sub plot and then changed into spikes $\mathrm{m}^{-2}$ accordingly. For measuring data on grains spike $^{-1}$, ten spikes were selected randomly in each sub plot, threshed separately, counted number of grains of each spikes and then averaged. Thousand grains weight was recorded by weighing thousand grains been taken randomly from grain lot of each sup plot. Data regarding biological yield was taken by reaping central four rows from every sub plot, sun dried, weighed and then changed to $\mathrm{kg} \mathrm{ha}^{-1}$ by using the formula:

Biological yield $\left(\mathrm{kg} \mathrm{ha}^{-1}\right)=\frac{\text { Biological yield }}{\mathrm{R}-\mathrm{R} \times \text { row length } \times \text { No. of rows }} \times 10000$

For grain yield the harvested four central rows in each sub plot were threshed, cleaned, weighed and changed into $\mathrm{kg} \mathrm{ha}^{-1}$ by formula:

Grain yield $\left(\mathrm{kg} \mathrm{ha}^{-1}\right)=\frac{\text { Grain yield }}{\mathrm{R}-\mathrm{R} \times \text { row length } \times \text { No. of rows }} \times 10000$

\section{Economic analysis}

The profitability of dual purpose wheat was calculated by the following formulae [10].

1. Gross income $=$ Grain yield value + straw yield value + forage yield value

2. Net income $=$ Gross income - total expenditure

\section{Statistical analysis}

Method applicable to the randomized complete block design (split-plot arrangement) was used for statistical analysis of the recorded data. For mean comparison in case of significant difference least significant difference (LSD) test at 5\% level of significance was used [11].

\section{Results and discussion}

\section{Fresh forage yield $\left(\mathrm{kg} \mathrm{ha}^{-1}\right)$}

Statistical analysis of the data revealed that nitrogen levels significantly affected fresh forage yield up to a certain level, but it was not increased by further increase of nitrogen (Table 1). This might be due to the fact that at this stage vegetative growth was not enough to fully utilize the higher dose of nitrogen. Higher fresh forage yield $(3874 \mathrm{~kg}$ $\mathrm{ha}^{-1}$ ) was produced by the plots treated with $140 \mathrm{~kg} \mathrm{~N} \mathrm{ha}^{-1}$, whereas control plots (treated with no nitrogen) produced lower forage yield $\left(2147 \mathrm{~kg} \mathrm{ha}^{-1}\right)$. Nitrogen stress leads to reduced plant growth [12]. Similar to [13] positive effect on wet and dry weight of wheat with nitrogen application was noticed.

\section{Spikes $\mathbf{~ m}^{-2}$ /productive tillers $\mathbf{~ m}^{-2}$}

Table1showed that decapitation and nitrogen rates had significant effect on spikes $\mathrm{m}^{-2}$ (productive tillers). Decapitation reduced spikes $\mathrm{m}^{-2}$ of wheat. Plots that receive no cut treatment resulted in highest (388) spikes $\mathrm{m}^{-2}$ while cut plots produced minimum (321) spikes $\mathrm{m}^{-2}$. Reduction in spikes $\mathrm{m}^{-2}$ in cut plots might be due to the fact that the 
treatment was applied at the time of stem elongation stage, because of which plants remained unable to produce any more tillers or even develop the already produced tillers [14]. Nitrogen application at the rate of 140 $\mathrm{kg} \mathrm{ha}{ }^{-1}$ produced more (389) spikes $\mathrm{m}^{-2}$ whereas less (274) spikes $\mathrm{m}^{-2}$ was by control plots. Similar results are reported by [15] who found that number of spikes $\mathrm{m}^{-2}$ enhanced up to $75 \mathrm{Kg} \mathrm{N} \mathrm{Fed}^{-1}$ (feddan = $0.42 \mathrm{ha}$ ). In the interaction of decapitation and nitrogen, spikes $\mathrm{m}^{-2}$ increased up to 140 $\mathrm{kg} \mathrm{N} \mathrm{ha}^{-1}$ in no cut plots whereas in cut plots spikes $\mathrm{m}^{-2}$ increased with increasing nitrogen (Fig. 1a).

\section{Grains spike ${ }^{-1}$}

Significant variation of decapitation stress and nitrogen levels on number of grains spike $^{-1}$ of wheat was revealed (Table 1). Number of grains spike $^{-1}$ of wheat significantly reduced by decapitation stress. More (53.2) grains spike ${ }^{-1}$ were produced by plants in no cut plots, while lesser (47.5) grains spike ${ }^{-1}$ were produced by plants in cut plots. The reduction in grains spike ${ }^{-1}$ might be due to strain induced by cutting during the vegetative stage of crop, which had removed green forage, the initially accumulated nutrients and shorten growth required for maximum economic yield production $[4,12]$. Nitrogen application up to a certain level enhanced number of grains spike $^{-1}$. Less (40.7) grain spike ${ }^{-1}$ were obtained in control while $140 \mathrm{~kg} \mathrm{~N} \mathrm{ha}{ }^{-1}$ produced more (56) grains spike ${ }^{-1}$. The reason may be that this is the optimum level of nitrogen for wheat crop. While in cut plots much of the nitrogen applied used to recover the vegetative and reproductive growth $[4,15,16]$. The interactive effect of decapitation and nitrogen showed increase in grains spike ${ }^{-1}$ with enhancing nitrogen levels up to $140 \mathrm{~kg} \mathrm{ha}^{-1}$ in no cut plots while in cut plots grains spike ${ }^{-1}$ increased up to $180 \mathrm{~kg} \mathrm{~N} \mathrm{ha}^{-1}$ (Fig. 1b).

\section{Thousand grains weight $(\mathrm{g})$}

Thousand grains weight was considerably reduced by decapitation stress, however significant increase was recorded with nitrogen application up to a certain level (Table 1). Heavier grains (39.43 g) were maintained by plants in no cut plots than cut plots. Decrease in thousand grains weight of wheat might be occurred when all or two top leaves were detached after 75 days of sowing [17]. Nitrogen, used at the rate of $140 \mathrm{~kg} \mathrm{ha}^{-1}$ resulted in higher thousand grains weight $(40.22 \mathrm{~g})$ which was statistically at par with $180 \mathrm{~kg} \mathrm{~N} \mathrm{ha}^{-1}$ (40.09 g). Optimum dose of nitrogen increased thousand grain weight of wheat $[4,15,16]$.

\section{Biological yield ( $\left.\mathrm{kg} \mathrm{ha}^{-1}\right)$}

Significant variation in biological yield of wheat was recorded by decapitation and nitrogen levels from statistical analysis of the data (Table 1). Decapitation significantly decreased biological yield. Highest biological yield (10856 kg ha ${ }^{-1}$ ) was maintained by no cut plots while cutting after 70 days of sowing produced lowest biological yield $\left(9535 \mathrm{~kg} \mathrm{ha}^{-1}\right)$. Stress induced by cutting in vegetative phase of the crop which removed much of the biomass compared to no cut plots and lowest number of tillers per unit area might be the probable reasons for decrease in biological yield [12, 14]. Biological yield significantly enhanced by nitrogen application. Biological yield of $11435 \mathrm{~kg} \mathrm{ha}^{-1}$ was produced by nitrogen applied at the rate of $180 \mathrm{~kg} \mathrm{ha}^{-1}$ which was at par of $140 \mathrm{~kg} \mathrm{~N} \mathrm{ha}^{-1}$. Lowest biological yield (7905 kg ha-1) was produced by $0 \mathrm{~kg} \mathrm{~N}$ $\mathrm{ha}^{-1}$. Nitrogen application linearly increased biological yield of wheat [12, 16]. Regarding interactive effect of decapitation and nitrogen levels biological yield increased with enhancing $\mathrm{N}$ levels in cut plots while in no cut treatment this liner increase was up to $140 \mathrm{~kg} \mathrm{~N} \mathrm{ha}^{-1}$ (Fig. 1c). 
Grain yield (kg ha-1)

Table1 revealed that decapitation stress and nitrogen levels had significant effect on grain yield of wheat. Decapitation considerably decreased grain yield. No cut plots produced highest grain yield $(3741 \mathrm{~kg}$ $\mathrm{ha}^{-1}$ ) while cutting after 70 days of sowing produced lowest grain yield (3209 $\left.\mathrm{kg} \mathrm{ha}^{-1}\right)$. Stress induced by cutting in vegetative phase of the crop might be the probable reason for decrease in grain yield because these practices reduced partitioning of assimilates in to sink. Light grains, less number of grains spike ${ }^{-1}$ and less number of fertile tillers are the other reasons for reduction in grain yield of wheat in cut plots or might be due to lowest leaf area index. Significant decrease in grain yield of wheat in cut plots was reported by many researchers $[4,14$, 16]. Nitrogen application at the rate of 180 $\mathrm{kg} \mathrm{ha} \mathrm{h}^{-1}$ produced maximum grain yield $\left(4246 \mathrm{~kg} \mathrm{ha}^{-1}\right)$ which is at par of $140 \mathrm{~kg} \mathrm{~N}$ $\mathrm{ha}^{-1}$. While the lowest grain yield $(1861 \mathrm{~kg}$ $\mathrm{ha}^{-1}$ ) was produced by control plots. Yield and yield components of wheat improved up to $150 \mathrm{~kg} \mathrm{~N} \mathrm{ha}^{-1}[16,18]$. Interaction of decapitation and nitrogen levels grain yield increased with enhancing $\mathrm{N}$ levels in cut and grazed plots while in no cut treatment this liner increase was up to $140 \mathrm{~kg} \mathrm{~N} \mathrm{ha}^{-1}$ (Fig. 1d).

Table 1. Spikes $\mathrm{m}^{-2}$, Fresh forage yield $\left(\mathrm{kg} \mathrm{ha}^{-1}\right)$, Grains spike ${ }^{-1}$, 1000-grains weight (g), Biological yield $\left(\mathrm{kg} \mathrm{ha}^{-1}\right)$ and Grain yield $\left(\mathrm{kg} \mathrm{ha}^{-1}\right)$ of wheat as affected by decapitation stress and nitrogen levels

\begin{tabular}{|c|c|c|c|c|c|c|}
\hline Treatment & $\begin{array}{c}\text { Spikes } \\
\mathrm{m}^{-2}\end{array}$ & $\begin{array}{c}\text { Fresh } \\
\text { forage } \\
\text { yield (kg } \\
\left.\text { ha }^{-1}\right)\end{array}$ & $\begin{array}{l}\text { Grains } \\
\text { spike }^{-1}\end{array}$ & $\begin{array}{c}1000- \\
\text { grains } \\
\text { weight }(g)\end{array}$ & $\begin{array}{c}\text { Biological } \\
\text { yield }(\mathrm{kg} \\
\left.\mathrm{ha}^{-1}\right)\end{array}$ & $\begin{array}{c}\text { Grain } \\
\text { yield }(\mathrm{kg} \\
\left.\mathrm{ha}^{-1}\right)\end{array}$ \\
\hline \multicolumn{7}{|c|}{ Decapitation stress (D) } \\
\hline No cut & $388 \mathrm{a}$ & 0000 & $53.2 \mathrm{a}$ & $39.43 \mathrm{a}$ & $10856 a$ & $3741 \mathrm{a}$ \\
\hline Cut & $321 b$ & 3243 & $47.5 \mathrm{~b}$ & $37.38 \mathrm{~b}$ & $9535 b$ & $3209 b$ \\
\hline $\operatorname{LSD}(0.05)$ & 6.55 & $\mathrm{~ns}$ & 1.37 & 0.57 & 138.12 & 23.01 \\
\hline \multicolumn{7}{|c|}{ Nitrogen $(N)\left(\mathrm{kg} \mathrm{ha}^{-1}\right)$} \\
\hline 0 & $274 d$ & $2147 d$ & $40.7 \mathrm{~d}$ & $35.37 \mathrm{c}$ & $7905 c$ & $1861 \mathrm{c}$ \\
\hline 100 & $342 c$ & $3124 \mathrm{c}$ & $48.2 \mathrm{c}$ & $38.4 \mathrm{~b}$ & $9668 b$ & $3401 b$ \\
\hline 140 & $389 a$ & $3874 a$ & $56.0 \mathrm{a}$ & $40.22 \mathrm{a}$ & $11328 \mathrm{a}$ & $4220 \mathrm{a}$ \\
\hline 180 & $379 b$ & $3783 b$ & $54.8 \mathrm{~b}$ & $40.09 \mathrm{a}$ & $11435 \mathrm{a}$ & $4246 a$ \\
\hline $\operatorname{LSD}(0.05)$ & 7.53 & 57.85 & 1.19 & 0.52 & 180.81 & 61.68 \\
\hline \multicolumn{7}{|c|}{ LSD $(0.05)$ for interaction } \\
\hline $\mathrm{D} \times \mathrm{N}$ & $*$ & $\mathrm{~ns}$ & * & Ns & $*$ & $*$ \\
\hline
\end{tabular}



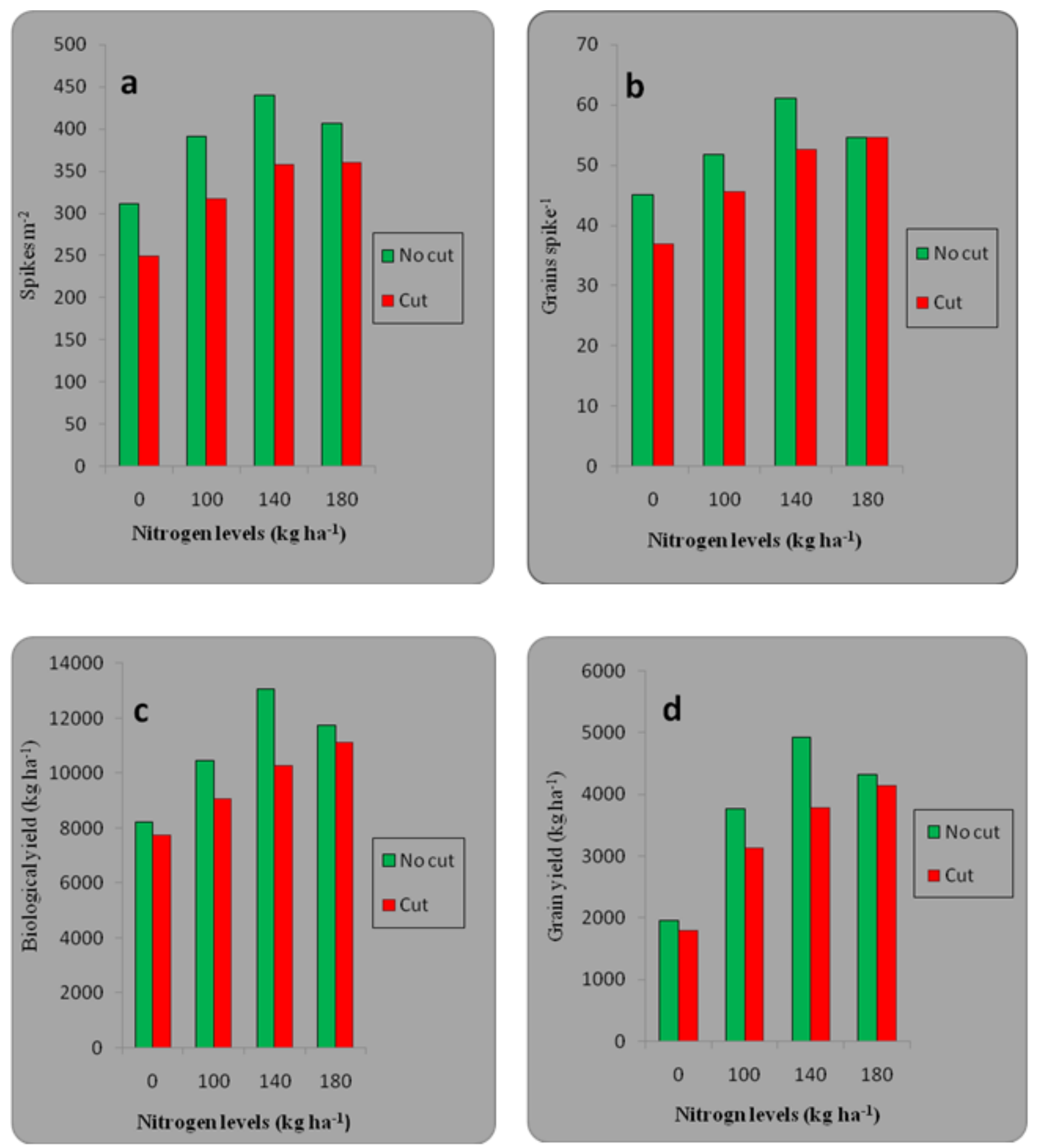

Figure 1. Spikes $\mathrm{m}^{-2}$ (a), grains spike $\mathrm{e}^{-1}$ (b), biological yield (c) and grain yield (d) of wheat as affected by the interaction of decapitation and nitrogen levels 


\section{Moisture content (\%)}

Table 2 showed that moisture content of wheat grains did not differ significantly due to decapitation stress, however the grains of cut plots showed more moisture content $(11.764 \%)$ than grains of no cut plots $(11.531 \%)$. Grain moisture content increased with each increment in nitrogen application. Higher moisture content (12.814\%) was recorded in plots received nitrogen at the rate of $180 \mathrm{~kg} \mathrm{ha}^{-1}$ while control plots resulted lower moisture content $(11.031 \%)$. A considerable increase in moisture content of wheat was also observed by the application of NPK fertilizers [19].

Table 2. Moisture content $(\%)$, Crude protein content $(\%)$ and Crude fiber content (\%) of wheat as affected by decapitation stress and nitrogen levels

\begin{tabular}{lccc}
\hline Treatment & $\begin{array}{c}\text { Moisture content } \\
(\%)\end{array}$ & $\begin{array}{c}\text { Crude protein } \\
\text { content }(\%)\end{array}$ & $\begin{array}{c}\text { Crude fiber content } \\
(\%)\end{array}$ \\
\hline Decapitation stress $(\mathbf{D})$ & 11.531 & 13.214 & 3.953 \\
No cut & 11.746 & 12.985 & 3.571 \\
Cut & $\mathrm{ns}$ & $\mathrm{Ns}$ & $\mathrm{Ns}$ \\
LSD $(0.05)$ & & & \\
Nitrogen $(\mathbf{N})\left(\mathbf{k g ~ h a}^{-\mathbf{1}}\right)$ & $11.031 \mathrm{~d}$ & $10.583 \mathrm{c}$ & 2.312 \\
0 & $11.544 \mathrm{c}$ & $11.532 \mathrm{~b}$ & 2.436 \\
100 & $12.132 \mathrm{~b}$ & $11.950 \mathrm{~b}$ & 2.343 \\
140 & $12.841 \mathrm{a}$ & $12.455 \mathrm{a}$ & 2.651 \\
180 & 0.47 & 0.45 & $\mathrm{Ns}$ \\
LSD $(0.05)$ & & & $\mathrm{N}$ \\
LSD $(\mathbf{0 . 0 5})$ for interaction & $\mathrm{ns}$ & $\mathrm{Ns}$ & $\mathrm{Ns}$ \\
D x N & & & \\
\hline
\end{tabular}

Means with different letters differ significantly according to Least Significant Difference (LSD) test $(P<0.05)$, ns stands for non-significant difference, and* for significant difference at $P<0.05$ level, respectively.

Net profit in Rs.

Decapitation significantly increased net returns of wheat (Table3). Cut plots gave maximum net income (Rs.131618 ha $\left.{ }^{-1}\right)$.

\section{Crude protein and fiber content $(\%)$}

Crude protein and crude fiber content of wheat grains showed non-significant variation for decapitation stress (Table2), Grain crude protein content increased with each increment in nitrogen application, while crude fiber content did not varied with increase in nitrogen dose. Higher protein content (12.455\%) was recorded in $180 \mathrm{~kg} \mathrm{~N}$ $\mathrm{ha}^{-1}$ treated plots which were statistically at far with $140 \mathrm{~kg} \mathrm{~N} \mathrm{ha}^{-1}$, while control plots resulted lower protein content $(10.583 \%)$. Protein content of wheat significantly increased with increase in nitrogen dose [20]. 
Table 3. Economic analysis of dual purpose wheat

\begin{tabular}{lccc}
\hline Effects & $\begin{array}{c}\text { Gross income } \\
\text { Rs. ha-1 }\end{array}$ & $\begin{array}{c}\text { Net income } \\
\text { Rs. ha }^{-1}\end{array}$ & $\begin{array}{c}\text { Net income over control } \\
\text { Rs. ha }^{-1}\end{array}$ \\
\hline Decapitation stress & & & \\
No cut & 136215 & 127551 & \\
Cut & 140882 & 131618 & 4067 \\
\hline
\end{tabular}

\section{Conclusion and recommendations}

Decapitation after 70 days sowing decreased $(16 \%)$ grain yield of wheat. But additional benefit in term of green fodder yield, exceed the loss of grain yield. Nitrogen application up to $140 \mathrm{~kg} \mathrm{ha}^{-1}$ enhanced grain yield however no significant increase in grain yield was observed with further increase in nitrogen levels. While linear increase in grain yield was observed in cut plots with increase of nitrogen. Application of nitrogen $140 \mathrm{~kg} \mathrm{ha}^{-1}$ with no decapitation stress for higher yield and yield components of wheat is recommended for the farmers of Peshawar valley.

\section{Authors' contributions}

Conceived and designed the experiments: $\mathrm{S}$ Anwar \& M Islam, Performed the experiments: M Islam, Data collections and field inspections: M Islam, Anjum, B Khan \& N Ali, Statistical analysis of the data: M Islam, WA Shah, M Ali \& N Khan, Contributed reagents/ materials/ analysis tools: N Khan, S Uddin \& M Ali, Wrote the paper: M Islam.

\section{References}

1. Arzadun MJ, Arroquy JI, Laborde HE \& Brevedan RE (2006). Effect of planting dates, clipping height and cultivars on forage and grain yield of winter wheat. Agron J 98: 1274-1279.

2. Krenzer EG (2000). Wheat is as forage. wheat management in Oklahoma. Oklahoma crop. Ext. Serv. and Oklahoma Agric. Exp. St. E-831. 27-30

3. Sharma BR. (1987). In Annual Report. Vivekanand Laboratory for Hill Agriculture. Almora. India. 81.
4. Khalil SK, Khan F, Rehman A, Muhammad F, Amanullah, Khan AZ, Shah MK \& Khan H (2011). Dual Purpose wheat for forage and grain yield in response to cutting, seed rate and nitrogen. Pak J Bot 43(2): 937-947.

5. Anonymous (2006). Govt. Pakistan, Ministry of food, agriculture and livestock. Econ Wing Islamabad 18-19.

6. Krenzer EG (1991). Wheat for pasture. OSU Ext. Facts 2586. Oklahoma Stat. Univ. Ext. Serv., Stillwater.

7. Zhang H, Johnson GV, Raun WR, Basta NT \& Hattey JA (1998). OSU. Soil test interpretations. Oklahoma Coop. Ext. Serv. and. Oklahoma Agric. Exp. Stn. F-2225. Oklahoma Stat. Univ. Stillwater.

8. Blumenthal JM, Baltensperger DD, Cassman KG, Mason SC \& Pavlivsta AD (2008). Importance and effect of nitrogen on crop quality and health. Agronomy-Faculty Publications. Paper 200. University of Nebraska.

9. Dean G \& Munford S. (2004). Evaluation of dual purpose cereal varieties. Tosmanian Institute of Agricultural Research. Annual Report.

10. CIMMYT (1988). An economic training manual; from agronomic data to farmer recommendations. Mexico 125.

11. Steel RGD \& Torrie JH (1984). Principles and procedure of statistics $2^{\text {nd }}$ ed Mc, Graw Hill, New York.

12. Noy-Meir I \& Briske DD (2002). Response of wild wheat populations to grazing in Mediterranean grassland: the 
relative influence of defoliation, competition, mulch and genotype. $J$ Appl Ecol 39(2): 259-278.

13. Fluegel SM \& Johnson JB (2001). The effect of soil nitrogen levels and wheat resistance on the Russian wheat aphid. Diuraphis noxia (Homoptera: Aphididae) J Kans Entomol Soc 74(1): 49-55.

14. Arif M, Khan MA, Akbar H, Sajjad \& Ali S (2006). Prospects of wheat as a dual purpose crop and its impact on weeds. Pak J Weed Sci Res 12(1-2): 1317.

15. Salwau MJM (1994). Effect of soil and foliar application of nitrogen levels on yield and yield components of wheat (Triticum aestivum L.). Ann Agric Sci Moshtohor 32(2): 705-715.

16. Afridi MZ, Jan MT \& Arif M (2010). Wheat yield components response to different levels of fertilizer-N application time and decapitation stress. Sarhad J Agric 26(4): 499-506.

17. Hulmel MB, Heumez E, Pluchard P, Beghin D, Departureaux C, Giraud A \& Gouis JL (2005). Indirect versus direct selection of winter wheat for low-input or high-input levels. 45: 1427-1431.

18. Mohammadi A, Rezvani M, Nezhad SZ \& Karamzadeh H (2012). Effect of nitrogen rate on yield and yield components of wheat in wild oat infested condition. Int J Agric Res And Review 2 (4): 496-503.

19. Sameen A, Niaz A \& Anjum FM (2002). Chemical composition of three wheat (Triticum aestivum L.) varieties as affected by NPK doses. Int $J$ Agric Bio 4(4): 537-539.

20. Alam MS (2012). Effect of sowing pattern and nitrogen rates on quality traits and yield of wheat. $J$ Environ Sci \& Natural Resources 5(1): 267-272. 